\title{
Host Plant Species of the Cicada Metcalfa Pruinosa in Romania
}

\author{
Mihai VLAD $^{1 *}$, Ioana GROZEA ${ }^{1}$ \\ ${ }^{1}$ Banat's University of Agricultural Sciences and Veterinary Medicine "King Michael I of Romania" from \\ Timisoara, 119 Calea Aradului, 300645 Timisoara, Romania. \\ *corresponding author, e-mail: speozarandbrad@yahoo.com
}

Bulletin UASVM series Agriculture 73(1)/2016

Print ISSN 1843-5246; Electronic ISSN 1843-5386

DOI 10.15835/buasvmcn-agr: 11383

\begin{abstract}
Metcalfa pruinosa (Say) is an invasive species native to North America, accidentally introduced to Europe, more specifically to Italy in 1979. In Romania it was observed for the first time in Constanta and a year later it was found in Timisoara, in the Western part of Romania too. In its place of origin the cicada consumes over 120 species of plants meanwhile in Europe, over 300, which indicates an emphasized polifagism.

The aim of our studies was to identify new host plants and habitats in Romania.

Observations took place in 13 counties of Romania in order to identity new host plants and habitats. Observations were performed in counties: Timis, Arad, Bihor, Hunedoara, Sibiu, Mures, Alba, Cluj, Mehedinti, Dolj, Salaj, Ilfov and Arges. The host plants were identified and the degree of attack was evaluated. The degree of attack was correlated with the number of host plants from an observation point. The number of attacked species was the highest in Timis county, where the degree of attack was also the highest, with an average value of 4.0. The most attacked plant species belonged to genera: Prunus, Buxus, Rosa, Hibiscus, Acer and Ligustrum. There is a positive correlation between the number of attacked plant species and the degree of attack. It has been found that where the diversity of plant species is high, Metcalfa pruinosa also has a larger population, and it is more likely to find the optimum plants for nutrition.
\end{abstract}

Keywords: cicada, host species, Metcalfa pruinosa, monitoring.

\section{INTRODUCTION}

Invasive species Metcalfa pruinosa (Say) is native to Nord America, specifically from nearctic ecozone, living in the eastern part of the continent, from Quebec to Mexic and Cuba (Metcalf and Bruner, 1948), from Texas to east of Colorado (Wilson and Lucchi, 2001), being present also in the Bermudas (Wilson and Hilburn, 1991). It was accidentally introduced to Europe throught Italy in 1979 (Lauterer 2002, Sacchetti et al. 2000; Zangheri and Donadini, 1980). In Romania it was observed for the first time in Constanta county in 2009(Preda and Skolka, 2009) and one year later it appeared in the western part of the country, in Timisoara (Grozea et al., 2011), meanwhile in Bucharest it was discovered in 2011 (Chirceanu and Gutue, 2011), (Fig.1).
Metcalfa pruinosa is an invasive species, occupying more and more territories (Nicoli, 1997). In the place of origin the cicada consumes over 120 species of plants, in Italy more than 280 plant species from 75 families, meanwhile in Europe it consumes around 300 species of plants (Alma et al., 2005, Bagnoli and Lucchi, 2000, Wilson and Lucchi, 2000), giving evidence of an emphasized polifagism. It conquers additional areas with imported plants that are infected with Metcalfa eggs. Previous studies show that longdistance spread of the species Metcalfa pruinosa or "the hitchhiker of Europe" is facilitated by vehicles and by the main means of transportation ( Vlad and Grozea, 2015). The aim of our studies was to identify new host plants and habitats in Romania. 


\section{MATERIALS AND METHODS}

The observations were made in 13 counties in Romania during 2014, from May to September in order to identify as many host plants as possible but also to discover new spreading areas. Observations took place in the following counties:
Timis; Arad; Bihor; Hunedoara; Sibiu; Mures; Alba; Cluj; Mehedinti; Dolj; Salaj; Ilfov si Arges.

71 observation points in the 13 counties were monitored. To have a larger diversity of areas, we conducted observations in public parks, entrances and exits of towns, vineyards, orchards and green

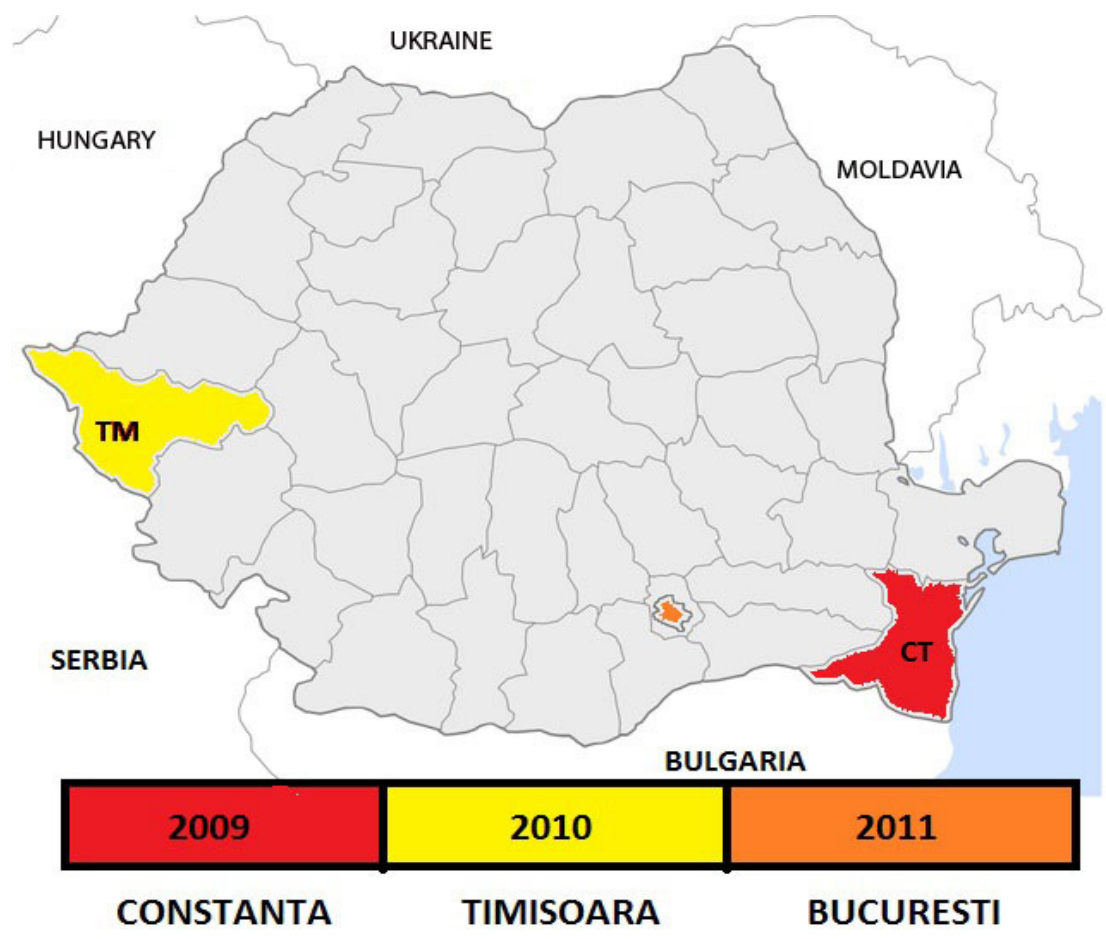

Fig.1 The evolution of Metcalfa pruinosa distribution in Romania

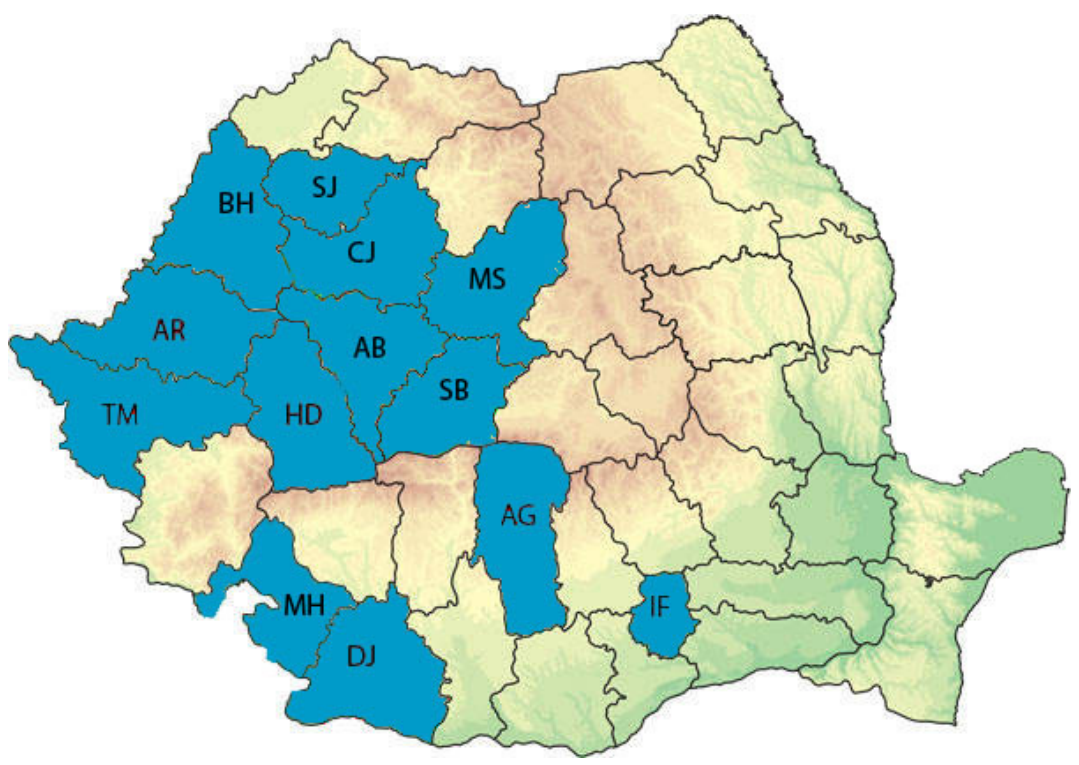

Fig. 2. Counties where monitoring of the ciada was performed in 2014 
areas between blocks of flats and around alleys. An observation point represents a distinct and well-defined green space with an area between 0.1-10 ha.

In observation points the presence or absence of the invasive species Metcalfa pruinosa was noted. At each point the GPS coordinates, the host plant species and the degree of attack were noted. Host plant was considered whether there were noticed several individuals (larvae and/or adults) and distinct signs of the attach (waxy secretions and honey dew) on the plant. The degree of the attack was rated on a scale from 0 to 5 , where 0 means the absense of the attack, and 5 is maximum attack, in which colonies of all generations were found on most of the plants.

\section{RESULTS AND DISCUSSION}

Of the 13 counties monitored in 2014 , cicada Metcalfa pruinosa was identified in 8 counties as can be seen in Figure 3. The species was found in the following towns: Timisoara, Lugoj and Faget (TM); Arad and Chisineu Cris (AR); Oradea (BH); Deva (HD); Strehaia and Drobeta -Turnu Severin

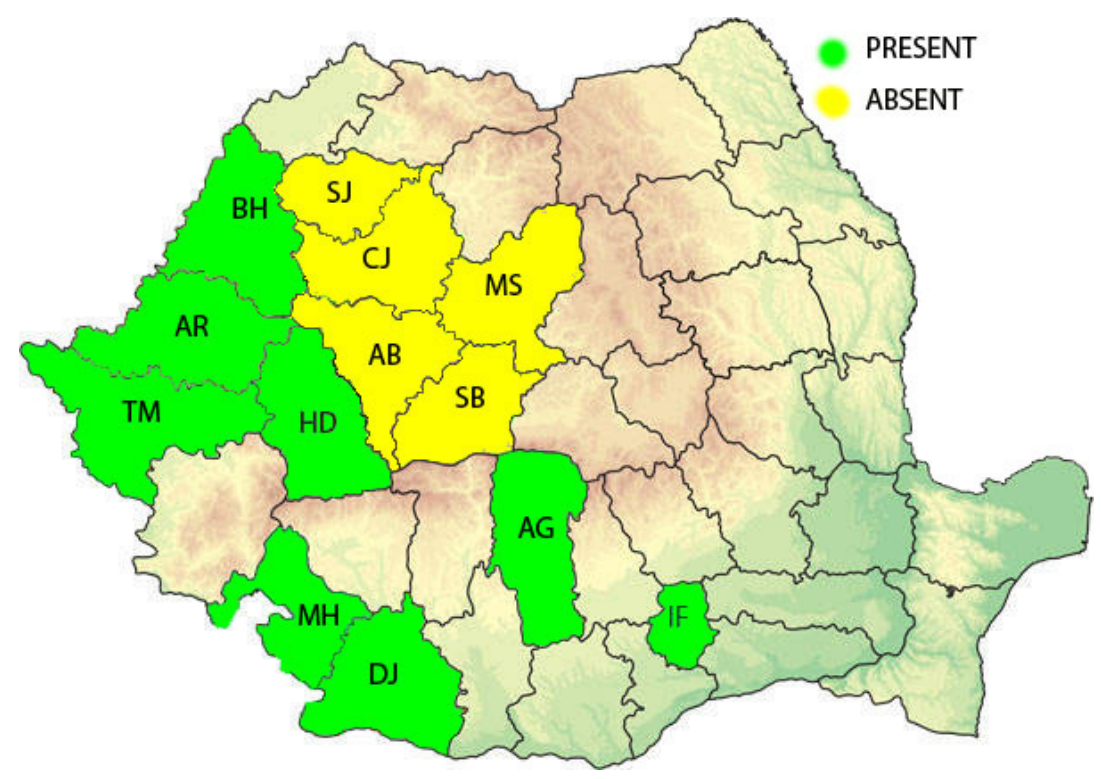

Fig. 3. Counties where invasive species Metcalfa pruinosa was identified in 2014 (counties colored in green signals the presence and yellow the presence of the cicada)

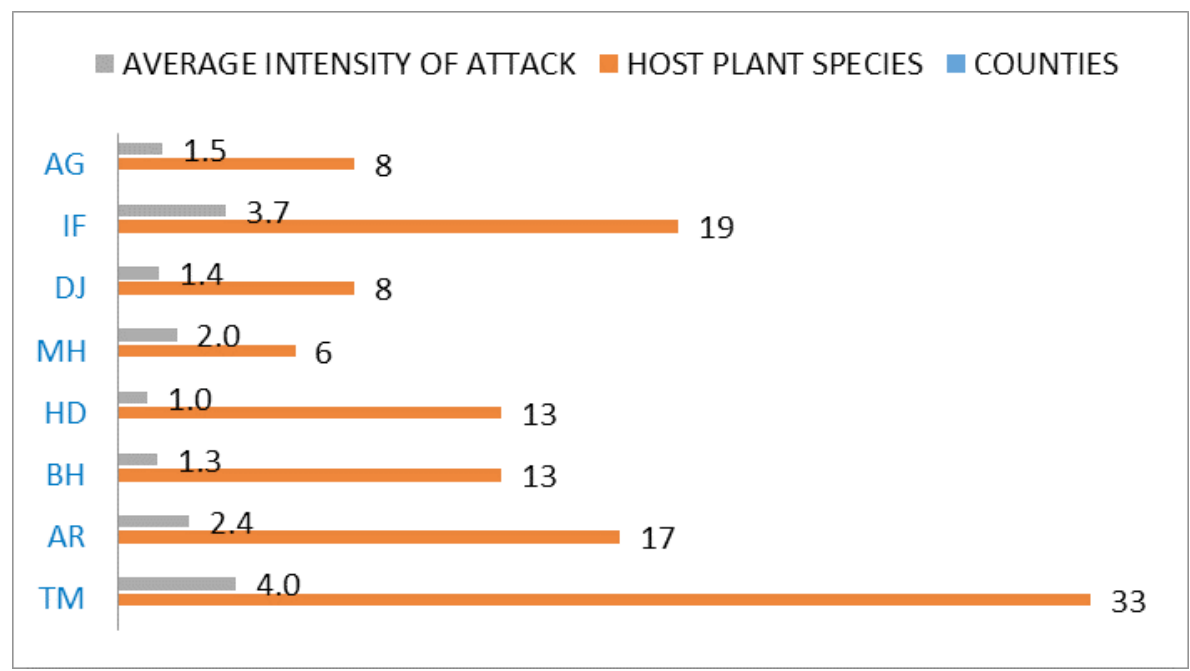

Fig. 4. The intensity of the attack and the number of host plants 
(MH); Craiova (Dolj); Cascioarele, near A1 highway (IF); Pitesti and Slatina (AG).

The number of species was correlated with the degree of attack from observation points as can be seen in Figure 4. Thus, the number of host species was the highest in Timis (33), where the degree of attack had an average of 4 . The lowest average number of attacked plants species was in Mehedinti county with a total of 6 species and an average degree of attack of 2 .

In the 8 counties where the cicada has been reported, Metcalfa pruinosa proved a very high polifagism, consuming 66 plant species from several families, as can be seen in Figure 5.

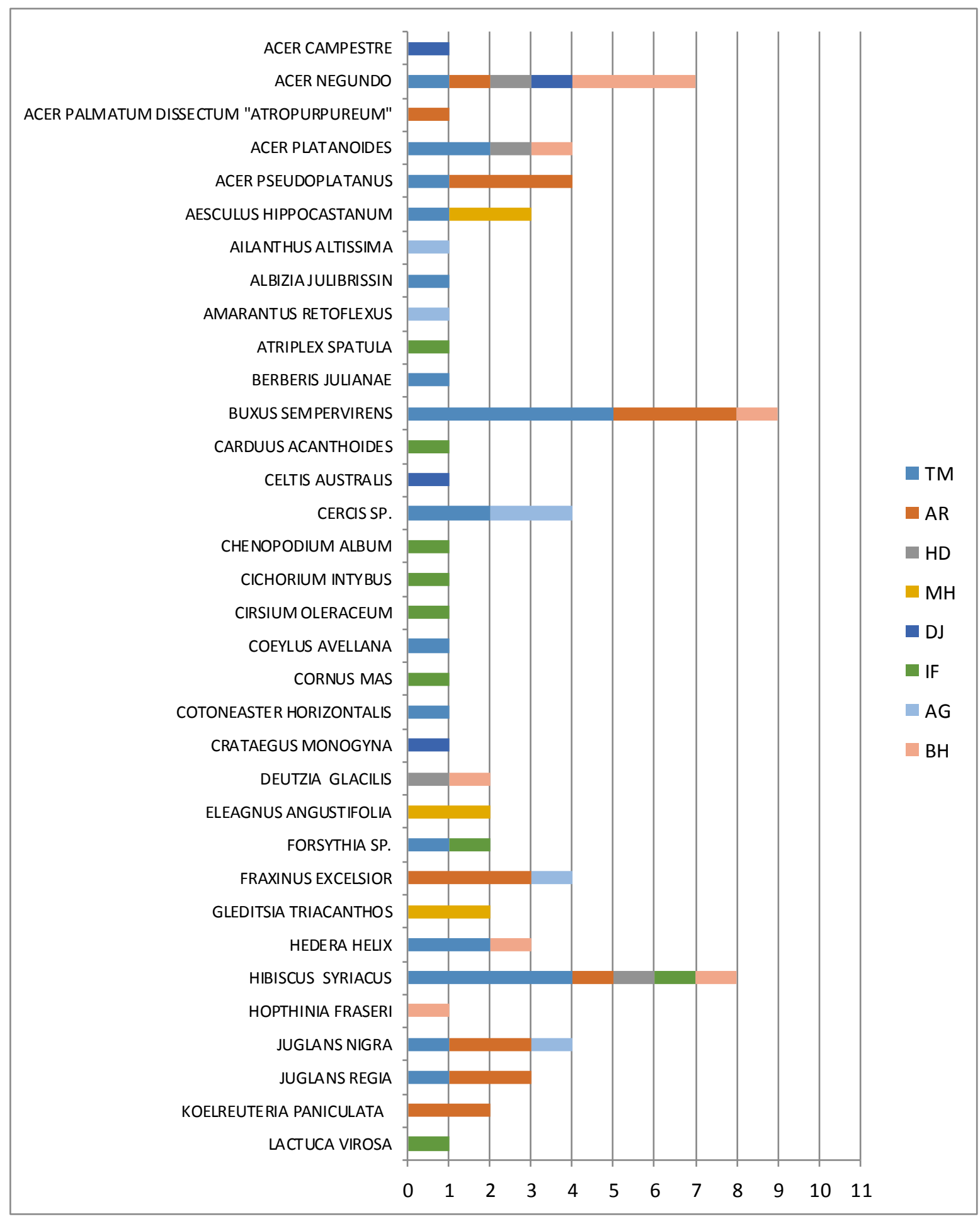




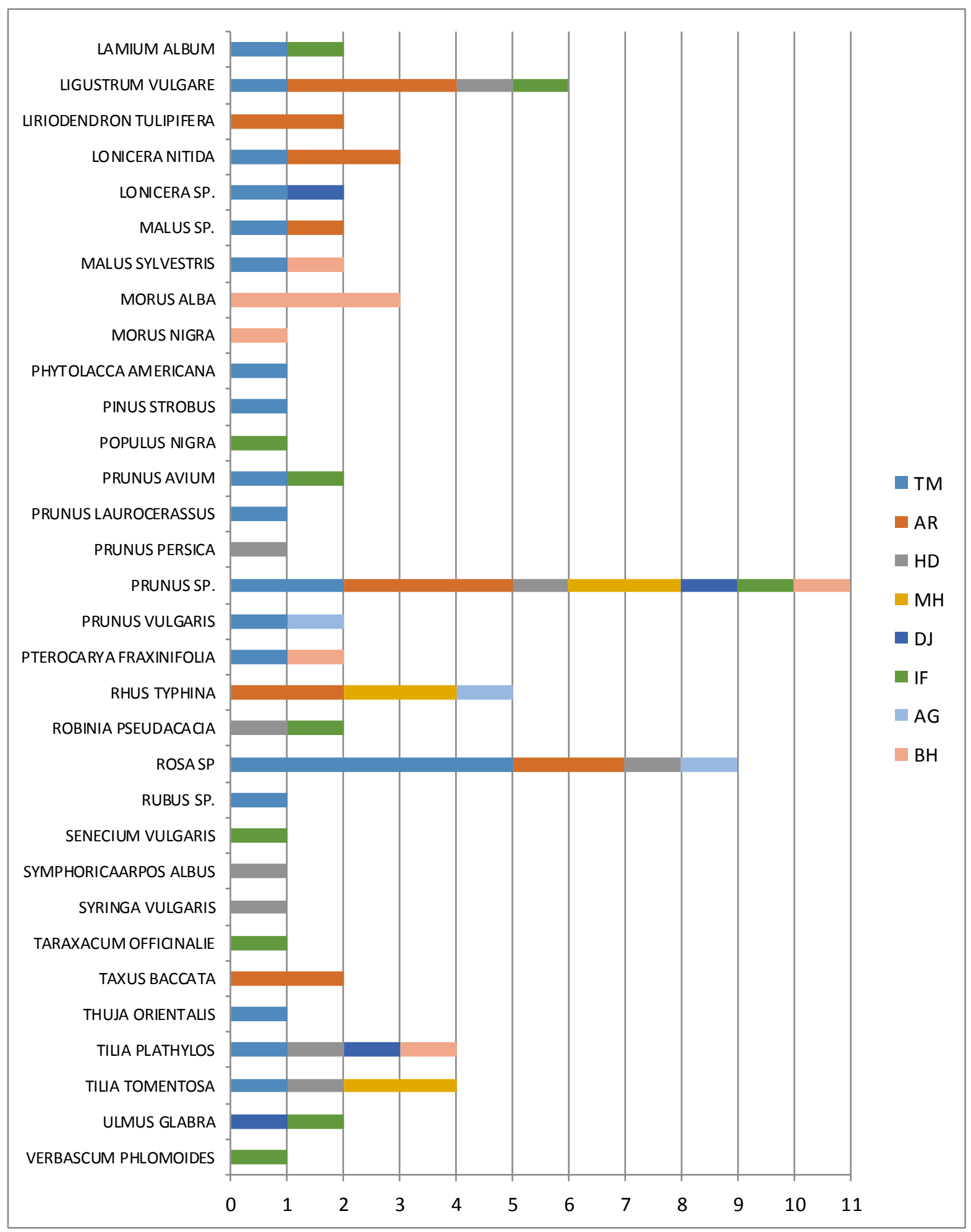

Fig. 5. Incidence of species attacked in the monitored counties

The most attacked plant species were from genus: Prunus, Buxus, Rosa, Hibiscus, Acer and Ligustrum. We also observed that gymnosperms are very rarely attacked, probably due to the morphological characteristics of stems and leaves, most of them often having needles or scale-like leaves with with thick, rough and waxy epiderm. 
There were 4 species identified from Prunus genus, besides a fifth chategory, which included various ornamental forms, with species that could not be identified. If the case of this genus, of 18 points in which the attack was reported, most were from Timis county.

Most of the attacked species were represented by trees or shrubs, with lignified stems. The explanation lies in the reproductive biology of the cicada, which is wintering through eggs laid under plants' bark. However, in strongly infested points the larvae reached herbaceous plants from the vicinity of host plants too. As larvae may move short distances on a few meters from the place of hatching, due to high populational level on host plants, a migration started. How spreading distance from year to year is short, on the order of several meters, a new habitat infestation occurs with greater speed in places with many woody species, in plantations with high density of plants, especially if the plant crown are touching. Also shaded areas, protected from winds are preferred.

It can be concluded that the range of infested species depends on the floristic composition of green spaces. If the attack is high enaugh, the cicada attacks actually any species, in extreme cases even conifers and herbaceous species of a specific area. The number of species actually attacked is not given only by the selectivity of the cicada, but also by the diversity of plant species. If a park is rich in plant species, yet few of them are attacked, it means that the attack is relatively recent, cicada consuming selectively species such as Prunus, Rosa, Hibiscus or Acer only when there is no populational stress. We can thus make an

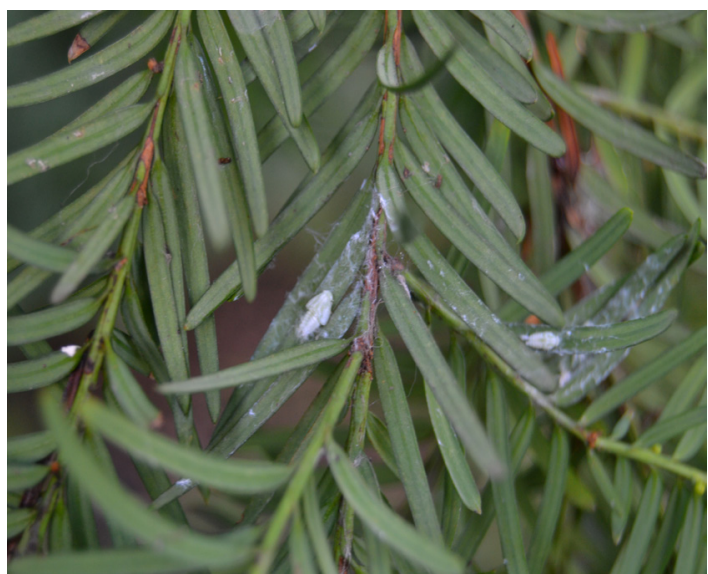

b.

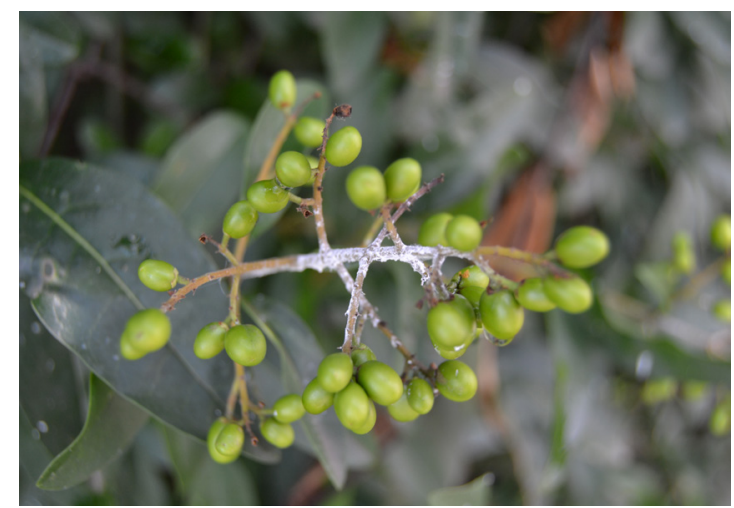

d.

Fig. 6. Host species of Metcalfa pruinosa: a) Buxus sempervirens b) Taxus baccata c) Rhus typhina d) Ligustrum vulgare 
estimation on when the cicada infested the area on the percentage of attacked species.

\section{CONCLUSION}

Of the 13 counties monitored in this study, the cicada has been reported in 8 counties, with a total of 66 plants species attacked.

Most attacked species were: Prunus, Buxus, Rosa, Hibiscus, Acer and Ligustrum.

There is a positive correlation between the number of host species and the degree of attack from a certain point of observation. It was found that where the diversity of host plants is high, the cicada Metcalfa pruinosa shows a high population level, with more likely to find optimal nutrition. However it was observed that in the case of a particularly strong attack the cicada can effectively attack any plant species which are available.

Most species of host plant were identified in Timis county which is also the area where the attack started in the western part of the country, therefore the installation period (since 2010) allowed assaulting a higher number of species.

Acknowledgments. I would like to thank to Dr.Brigitta Schmidt for scientific support in identification of plant species and in monitoring activities.

\section{REFERENCES}

1. Alma A., Ferracini C. \& Burgio G. (2005) Development of a sequential plant to evaluate Neodryinus typhlocybae (Ashmead) (Hymenoptera: Dryinidae) population associated with Metcalfa pruinosa (Say) (Homoptera: Flatidae) infestation in Northwestern Italy. Environmental Entomology, 34(4): 819-824.

2. Bagnoli, B. and A. Lucchi. 2000. Dannosità e misure di controllo integrato, 65-88. In, A. Lucchi (Editor). La Metcalfa negli ecosistemi italiani. Agenzia Regionale per lo Svilluppo e l'Innovazione nel settore Agricolo-forestale, Firenze, Italy. 163.
3. Chirceanu and Gutue, 2011. Metcalfa pruinosa (Say) (Hemiptera:Flatidae) identified in a new south eastern area of Romania (Bucharest Area). Romanian Journal of Plant Protection Vol.4, 28-24.

4. Grozea, I., Gogan, A., Virteiu, A.M., Grozea, A., Stef, R., Molnar, L., Carabet, A. and Dinnesen, S. (2011) Metcalfa pruinosa Say (Insecta: Homoptera: Flatidae): a New pest in Romania. African Journal of Adricultural Research 6 (27): 5870-5877.

5. Lauterer, P. (2002) Citrus Flatid Planthopper - Metcalfa pruinosa (Hemiptera: Flatidae), a New Pest of Ornamental Horticulture in the Czech Republic. Plant Protection Science, 38(4): 145-148.

6. Metcalf ZP, Bruner SC, 1948. Cuban Flatidae with new species from adjacent regions. Annals of the Entomological Society of America, 41:63-118.

7. Nicoli G. (1997) Biological control of exotic pests in Italy: recent experiences and perspectives. OEPP/EPPO Bull 27: 69-75.

8. Preda C., Skolka M. 2009. First record of a new alien invasive species in Constanta - Metcalfa pruinosa (Homoptera: Fulgoroidea). In:Păltineanu C. 2009 Lucrările Simpozionului Mediul si agricultura în regiunile aride, Prima editie, Bucuresti (Romania). 141-146.

9. Sacchetti, P., A. Guidotti, and P. Braccini. 2000. Impiego di Neodryinus typhlocybae in Toscana, pp. 131-158. In, A. Lucchi (Editor). La Metcalfa negli ecosistemi italiani. Agenzia Regionale per lo Svilluppo e l'Innovazione nel settore Agricolo-forestale, Firenze, Italy. 163.

10. Vlad M., Grozea I., 2015. Researches regarding the expansion of Metcalfa pruinosa (say) in Romania (2): 99103.

11. Wilson S. W., Lucchi A., 2000.- Aspetti sistematici, corologici, ecologici, pp. 13-26. In: La Metcalfa negli ecosistemi italiani (LUCCHI A., Ed.).- ARSIA, Firenze, Italy.

12. Wilson S. W., Lucchi A., 2001.- Distribution and ecology of Metcalfa pruinosa and associated planthoppers in North America (Homoptera: Fulgoroidea).- Atti della Accademia nazionale italiana di Entomologia, Rendiconti, 49: 121130.

13. Wilson, M. R. and D. J. Hilburn. 1991. Annotated list of the auchenorrhynchous Homoptera (Insecta) of Bermuda. Annals of the Entomological Society of America 84:412419.

14. Zangheri, S. and P. Donadini, 1980. Comparsa nel Veneto di un omottero neartico: Metcalfa pruinosa Say (Homoptera, Flatidae). Redia 63, 301-305. 